\title{
Efektifitas Penggunaan Media Audiovisual dan Aplikasi Permitasi Terhadap Pengetahuan dan Kepatuhan Ibu Meminum Tablet Besi
}

\section{The effectiveness of Audio-visual media use and Permitasi app for mothers' knowledge and the consumption compliance of Iron tablets}

\author{
Annisa Raufiah Fertimah ${ }^{1 *}$, Sri Mulyani ${ }^{2}$, Widyawati ${ }^{3}$ \\ ${ }^{1}$ Program Studi IImu Keperawatan Fakultas Kedokteran Kesehatan Masyarakat dan \\ Keperawatan Universitas Gadjah Mada \\ ${ }^{2}$ Departemen Keperawatan Jiwa dan Komunitas, Fakultas Kedokteran, Kesehatan \\ Masyarakat, dan Keperawatan, Universitas Gadjah Mada \\ ${ }^{3}$ Departemen Keperawatan Anak dan Maternitas, Fakultas Kedokteran, Kesehatan \\ Masyarakat, dan Keperawatan, Universitas Gadjah Mada
}

\begin{abstract}
Background: One cause of anemia in pregnancy is mothers' non-compliance in consuming iron tablet supplement because of the knowledge insufficiencies regarding anemia and the importance of iron tablet consumptions. Knowledge and compliance of pregnant mothers can be improved through health education using appropriate technology and media. Nowadays, health education is pre-dominated by conventional methods. However, audiovisual, and android applications are rarely used.

Objective: To identify the effect of audiovisual health education and Pemitasi app (an android application for reminding user to consume iron tablet supplement) toward knowledge about anemia and pregnant mothers' compliance in taking iron tablet supplement and to determine the correlation between anemia knowledge and compliance in taking iron tablet supplement.

Methods: This research was a quasi-experimental design with one group pretest posttest design. The sample of research consisted of 60 pregnant women who received iron tablets and owned an android smartphone. Sample was recruited using consecutive sampling methods. Research instruments were questionnaire and daily iron tablet supplement consumption control form. Data was analyzed using Wilcoxon test and Spearman's rho correlation test.

Results: Result: The mean knowledge score before and after audiovisual media intervention were 75,70 and 91,43 . In addition, the mean scores of compliance before and after the Pemitasi app intervention were 79,50 and 93,67 . What is more, there were significant results between pre-test and post-test knowledge level $(p=0,001)$ and compliance $(p=0,001)$. Also, there was a significant relationship between the knowledge and compliance of pregnant women in consuming iron tablets $(p=0,002)$.

Conclusion: Providing health education using audiovisual media and Pemitasi app improve pregnant women's knowledge of anemia and their consumption compliance of iron tablets.
\end{abstract}

Keywords: anemia, audiovisual, compliance, Pemitasi application, pregnant women

\section{ABSTRAK}

Latar Belakang: Salah satu penyebab masalah anemia pada ibu hamil adalah ketidakpatuhan ibu dalam mengonsumsi tablet besi karena kurangnya pengetahuan tentang anemia dan pentingnya mengkonsumsi tablet besi. Pengetahuan dan kepatuhan ibu hamil dapat ditingkatkan melalui pendidikan kesehatan menggunakan teknologi dan media yang tepat. Saat ini, pendidikan kesehatan masih menggunakan metode konvensional. Namun, metode audiovisual dan aplikasi masih jarang dilakukan.

Tujuan: Mengetahui pengaruh pemberian media audiovisual dan aplikasi Pemitasi (aplikasi android sebagai pengingat minum tablet besi) terhadap pengetahuan tentang anemia dan kepatuhan minum tablet besi pada ibu hamil, serta mengetahui hubungan pengetahuan dengan kepatuhan. 
Metode: Penelitian ini merupakan penelitian kuasi-eksperimental dengan rancangan one group pre-test post-test. Sampel pada penelitian ini sebanyak 60 ibu hamil di salah satu Puskesmas di Kabupaten Bantul yang menerima tablet besi dan memiliki smartphone berbasis android yang dipilih dengan teknik consecutive sampling. Alat pengumpulan data menggunakan kuesioner dan format kontrol harian konsumsi tablet besi. Analisis data menggunakan uji Wilcoxon dan uji korelasi Spearman's rho.

Hasil: Hasil rata-rata skor pengetahuan sebelum pemberian media audiovisual sebesar 75,70 dan sesudah perlakuan sebesar 91,43 . Hasil rata-rata skor kepatuhan sebelum pemberian aplikasi Pemitasi sebesar 79,50 dan sesudah perlakuan sebesar 93,67. Terdapat perbedaan signifikan antara hasil pretest dan post-test pada tingkat pengetahuan $(p=0,001)$ dan kepatuhan $(p=0,001)$. Terdapat hubungan yang signifikan antara pengetahuan dan kepatuhan ibu hamil dalam mengkonsumsi tablet besi $(p=$ 0,002).

Kesimpulan: Pemberian edukasi kesehatan melalui media audiovisual dan aplikasi Pemitasi berpengaruh dalam meningkatkan pengetahuan ibu hamil tentang anemia dan kepatuhan minum tablet besi.

Kata kunci: anemia, aplikasi Pemitasi, audiovisual, kepatuhan, ibu hamil

\section{PENDAHULUAN}

Menurut World Health Organization (WHO), ${ }^{1}$ Indonesia menduduki peringkat pertama Angka Kematian Ibu (AKI) dari 181 negara di dunia, dan 28\% penyebab utama dari kematian ibu adalah terjadinya perdarahan. Adapun salah satu penyebab utama perdarahan adalah anemia. Selain mengakibatkan perdarahan, anemia defisiensi besi pada ibu hamil meningkatkan risiko kelahiran prematur dan berat badan lahir rendah. ${ }^{2}$ Anemia defisiensi besi merupakan salah satu anemia yang paling banyak ditemui pada kehamilan. ${ }^{3}$

Anemia dapat terjadi pada masa kehamilan jika kadar Hemoglobin dalam darah pada ibu hamil kurang dari $11 \mathrm{~g} / \mathrm{dl}$ pada trimester pertama dan ketiga, serta kurang dari 10,5 g/dl pada trimester kedua. ${ }^{4}$ Pada tahun 2011 , wanita hamil dengan anemia di dunia sebesar $38 \% .{ }^{1} \mathrm{Di}$ Indonesia, proporsi anemia pada ibu hamil sebesar 37,1\%. Sementara di Provinsi Yogyakarta, angka kejadian anemia pada ibu hamil pada tahun 2011 tercatat sebesar 18,90\%, dan yang tertinggi berada di Kabupaten Bantul sebesar 25,60\%. ${ }^{5}$

Pemerintah Indonesia membuat program pemberian 90 tablet besi $(\mathrm{Fe})$ untuk mencegah dan mengatasi masalah anemia pada kehamilan. ${ }^{6}$ Upaya pencegahan terjadinya anemia pada ibu hamil melalui program pemberian tablet besi telah dilaksanakan di Kabupaten Bantul. lbu hamil diberikan tablet besi sebanyak 90 tablet selama masa kehamilan yang terbagi dalam tiga kali pemberian (Fe1, Fe2, dan Fe3). Pada tahun 2015, cakupan tablet besi (Fe1 dan Fe3) yang didapatkan ibu hamil sebanyak $94,17 \%$ untuk Fe1 dan $84,57 \%$ untuk Fe3. ${ }^{7}$ Berdasarkan hasil Riskesdas pada tahun 2013, menunjukkan dari 89,1\% ibu hamil yang mengonsumsi tablet $\mathrm{Fe}$, hanya sepertiga (33,3\%) yang mengonsumsi lengkap sampai 90 tablet Fe sesuai anjuran. ${ }^{8}$

Proporsi cakupan pemberian tablet besi Fe1 dan Fe3 pada ibu hamil di Kabupaten Bantul sudah cukup tinggi, akan tetapi prevalensi kejadian anemia pada ibu hamil juga masih tinggi. Adapun salah satu penyebab masalah anemia pada ibu hamil adalah gagalnya kepatuhan ibu 
dalam mengonsumsi tablet besi pada masa kehamilan karena kurangnya pengetahuan mengenai anemia serta pentingnya mengkonsumsi tablet besi pada saat hamil. ${ }^{9}$

Pengetahuan ibu hamil tentang anemia dapat ditingkatkan melalui pendidikan kesehatan. Pendidikan kesehatan bertujuan mengubah perilaku kesehatan, ${ }^{10}$ dimana salah satu faktor yang dapat memengaruhi perilaku adalah tingkat pengetahuan seseorang. ${ }^{11}$ Semakin tinggi tingkat pengetahuan, maka semakin tinggi kesadaran ibu hamil untuk mencegah terjadinya anemia. $^{12}$

Penggunaan teknologi dan media pembelajaran merupakan suatu upaya dalam meningkatkan kualitas pembelajaran atau pendidikan. ${ }^{13}$ Penggunaan media pendidikan dapat digunakan sebagai alat untuk membantu menyampaikan pesan kesehatan. Salah satu contoh media yang dapat digunakan adalah audiovisual dan aplikasi. Menggunakan media audiovisual, mengaktifkan pancaindra pendengaran dan penglihatan sekaligus, serta terbukti memiliki tingkat efektivitas 50\% lebih tinggi dibanding tanpa media audiovisual. ${ }^{14}$ Penelitian ini menggunakan aplikasi Pemitasi (Pengingat Minum Tablet Besi) yang dibuat sebagai pengingat atau alarm untuk ibu hamil dalam meminum tablet besi. Aplikasi Pemitasi ini belum pernah digunakan dalam penelitian sebelumnya. Penelitian ini dilakukan di salah satu Puskesmas Pelayanan Obstetri Neonatal Emergensi Dasar (PONED) di Kabupaten Bantul.

Tujuan penelitian ini adalah untuk mengetahui pengaruh pemberian Pendidikan Kesehatan mengenai anemia menggunakan media audiovisual dan aplikasi Pemitasiterhadap tingkat pengetahuan tentang anemia dan kepatuhan minum tablet besi pada ibu hamil dan untuk mengetahui hubungan pengetahuan ibu hamil tentang anemia dengan kepatuhan minum tablet besi.

\section{METODE PENELITIAN}

Penelitian ini menggunakan jenis penelitian quasi-experimental design dengan rancangan one group pre-test post-test. Penelitian dilakukan di salah satu puskesmas PONED di Kabupaten Bantul pada tanggal 1 Desember 2017 - 15 Januari 2018. Setelah mendapatkan persetujuan kelayakan etik dari komisi etik FK-KMK UGM. Puskesmas tersebut terpilih secara acak dari enam puskesmas PONED di Kabupaten Bantul.

Sampel penelitian adalah 60 ibu hamil yang memeriksakan kehamilannya di salah satu puskesmas PONED di Kabupaten Bantul. Sampel diambil menggunakan teknik Consecutive sampling ${ }^{11}$, dengan menggunakan kriteria inklusi dan eksklusi. Kriteria inklusi adalah ibu hamil trimester I-III yang menerima tablet besi, memiliki handphone berbasis android, dapat membaca dan menulis, mampu berkomunikasi dengan lancar, dan bersedia menjadi responden. Kriteria eksklusi adalah ibu hamil yang memiliki penyakit penyerta dan risiko tinggi seperti TBC, pneumonia, hipertensi. Penghitungan besar sampel menggunakan rumus 
Slovin. ${ }^{15}$ Pada penelitian ini semua responden mengikuti program secara keseluruhan, sehingga tidak ada sampel yang drop out.

Data pengetahuan responden diperoleh melalui kuesioner yang diadopsi dari penelitian Sulistiyowati ${ }^{16}$ yang berjudul "Tingkat Pengetahuan Ibu Hamil tentang Anemia di Puskesmas Gambirsari Surakarta”. Kuesioner tersebut terdiri dari 30 soal yang dimodifikasi menjadi 20 soal untuk menyesuaikan dengan tujuan. Kuesioner penelitian berisi pertanyaan mengenai pengetahuan, etiologi, tanda dan gejala, batasan anemia, macam anemia, dampak anemia, serta pencegahan anemia. Hasil uji validitas yang dilakukan pada 110 orang ibu hamil dan dilakukan penghitungan, didapatkan nilai $r_{\text {hitung }}>r_{\text {tabel }}(0,1874)$. Hasil uji reliabilitas didapatkan nilai koefisien Alpha 0,659 > 0,6.

Data kepatuhan responden diperoleh melalui format kontrol harian konsumsi tablet besi yang diadopsi dari Widyawati. ${ }^{17}$ Pengisian format kontrol harian dengan cara mengisi tanggal dan memberi tanda check $(\sqrt{ })$ pada salah satu kolom jika sudah meminum tablet besi pada kolom P (Pagi), S (Siang), atau M (Malam).

Pengolahan data dilakukan dengan bantuan program komputer. Pengaruh pemberian pendidikan Kesehatan menggunakan media audiovisual dan penggunaan aplikasi Pemitasi terhadap pengetahuan dan kepatuhan diukur menggunakan uji non-parametric Wilcoxon karena data tidak terdistribusi normal. ${ }^{18}$ Hubungan pengetahuan dan kepatuhan diukur menggunakan uji korelasi Spearman's rho karena data tidak terdistribusi normal. ${ }^{19}$ Pengujian normalitas data menggunakan uji Kolmogorof-Smirnov.

Penelitian ini memiliki ethical approval dengan nomor KE/FK/1130/EC/2017 yang diterbitkan pada 20 Oktober 2017 oleh komisi etik FK-KMK UGM. Peneliti dibantu oleh 3 orang asisten untuk membantu dalam membagikan kuesioner, mempersiapkan pemutaran media audiovisual, mengirim aplikasi Pemitasi kepada responden, dan menjelaskan hal-hal yang kurang jelas dalam kuesioner. Sebelumnya dilakukan pelatihan untuk asisten mengenai penelitian yang akan dilakukan, memberikan penjelasan mengenai cara penggunaan kuesioner dan aplikasi Pemitasi.

\section{HASIL}

Jumlah sampel dalam penelitian ini adalah 60 ibu hamil. Gambaran karakteristik responden dapat dilihat pada Tabel 1. Sebagian besar responden memiliki usia 21-35 tahun, tingkat pendidikan SMA dan Perguruan Tinggi, tidak bekerja atau sebagai ibu rumah tangga dan status paritas 2-4 kali kehamilan. Sebagian responden hanya mendapatkan informasi dari petugas kesehatan, memiliki kadar $\mathrm{Hb} \geq 11 \mathrm{gr} / \mathrm{dL}$. Sebanyak $66,7 \%$ suami berperan dalam meningkatkan kepatuhan responden meminum tablet besi. Sebesar $95 \%$ ibu hamil mengulang memutar video. 
Tabel 1. Distribusi frekuensi karakteristik responden ibu hamil yang menerima tablet besi $(n=60)$

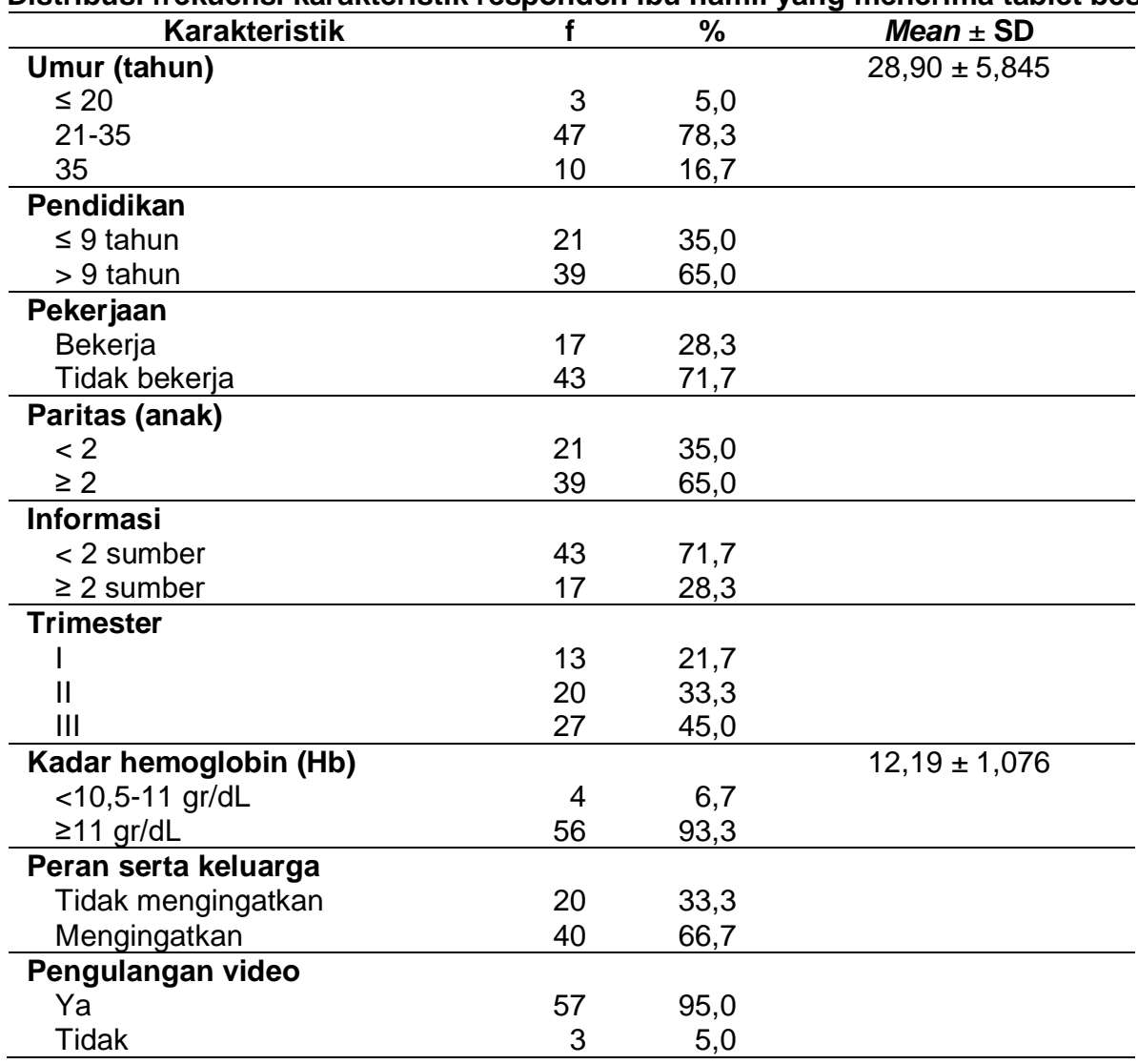

Pada saat pre-test dan post-test 1 (pengetahuan) 60 ibu hamil mengisi kuesioner secara langsung. Pada saat post-test 2 (pengetahuan dan kepatuhan) ada 37 ibu hamil yang mengikuti post-test melalui daring via WhatsApp (Tabel 2).

Gambaran tingkat pengetahuan ibu hamil yang melakukan pemeriksaan Antenatal Care (ANC) di Puskesmas di Bantul sebagian besar dalam kategori lebih dari nilai rata-rata (mean) yaitu sebesar 55\%. Setelah dilakukan post-test, pengetahuan responden mengalami peningkatan sebesar $41,7 \%$, sehingga responden yang masuk dalam kategori >mean menjadi $96,7 \%$ atau dari 33 responden menjadi 58 responden.

Tabel 2. Gambaran tingkat pengetahuan tentang anemia dan kepatuhan minum tablet besi sebelum dan sesudah intervensi $(n=60)$

\begin{tabular}{lrrrr}
\hline \multirow{2}{*}{ Variabel } & \multicolumn{2}{c}{ Pre-test } & \multicolumn{2}{c}{ Post-test } \\
\cline { 2 - 5 } & f & $\%$ & f & $\%$ \\
\hline Pengetahuan & & & & \\
$\quad$ mean & 33 & 55,0 & 58 & 96,7 \\
$\quad$ mean & 27 & 45,0 & 2 & 3,3 \\
\hline Kepatuhan & & & & \\
Patuh & 25 & 41,7 & 55 & 91,7 \\
Tidak patuh & 35 & 58,3 & 5 & 8,3 \\
\hline
\end{tabular}

Saat dilakukan pre-test diperoleh hasil kepatuhan sebesar $41,7 \%$, responden masuk dalam kategori patuh dalam mengonsumsi tablet besi. Pengambilan data awal (pre-test) kepatuhan dengan cara menghitung selisih jumlah tablet besi (Fe) yang diterima ibu hamil 
dengan jumlah tablet besi yang telah dikonsumsi sesuai dengan dosis yang seharusnya dan dikalikan $100 \%$. Dari hasil penghitungan, ibu hamil dikatakan patuh apabila mengonsumsi tablet besi $<90 \% .{ }^{20}$ Setelah dilakukan intervensi menggunakan aplikasi Pemitasi dan dilakukan post-test, kepatuhan responden mengalami peningkatan sebesar $50 \%$, sehingga responden yang masuk dalam kategori patuh menjadi $91,7 \%$ atau dari 25 responden menjadi 55 responden.

Sebelum pemberian edukasi tentang anemia pada kehamilan, dilakukan pre-test untuk mengetahui tingkat pengetahuan responden sebelum dilakukan intervensi. Setelah dilakukan intervensi, dilakukan post-test 1 pengetahuan dan post-test 2 pengetahuan dengan jarak waktu 10 hari setelah dilakukan intervensi.

Tabel 3. Gambaran hasil pengetahuan tentang anemia pada kehamilan dan kepatuhan minum tablet besi pada ibu hamil

\begin{tabular}{llcc}
\hline & Test & Mean Skor Test & p value \\
\hline Pengetahuan & Pre-test & 75,70 & \multirow{2}{*}{$0,001^{\mathrm{a}}$} \\
& Post-test 1 & 88,20 & \\
& Post-test 2 & 91,43 & $0,001^{\mathrm{b*}}$ \\
\hline Kepatuhan & Pre-test & 79,50 & \multirow{2}{*}{$0,001^{*}$} \\
& Post-test & 93,67 & \\
\hline
\end{tabular}

Keterangan:

*signifikansi $<0,05$

anilai signifikansi pre-test dengan post-test 1

bnilai signifikansi pre-test dengan post-test 2

Hasil pre-test dan post-test 1 untuk pengetahuan tentang anemia mengalami peningkatan rata-rata sebesar 12,08 ( $<<0,05)$. Hasil pre-test dan post-test 2 mengalami peningkatan ratarata sebesar 15,66 $(p<0,05)$ (Tabel 3).

Sebelum diberikan aplikasi Pemitasi, responden diminta mengisi formulir data awal yang digunakan sebagai pre-test untuk mengetahui tingkat kepatuhan sebelum pemberian intervensi. Setelah dilakukan intervensi, dilakukan post-test kepatuhan dengan jarak waktu 10 hari setelah dilakukan intervensi. Hasil pre-test dan post-test untuk kepatuhan konsumsi tablet besi mengalami peningkatan rata-rata sebesar 14,07 ( $p<0,05)$ (Tabel 3).

Pengetahuan dikategorikan menjadi 2 kelompok yaitu kelompok lebih besar dari mean dan kelompok lebih kecil dari mean. Sementara, kepatuhan juga dikategorikan menjadi 2 kelompok yaitu patuh dan tidak patuh, yang dijelaskan pada Tabel 4.

Tabel 4. Pengukuran hubungan pengetahuan tentang anemia dengan kepatuhan minum tablet besi pada ibu hamil $(n=60)$

\begin{tabular}{|c|c|c|c|c|c|c|c|}
\hline \multirow{3}{*}{$\begin{array}{l}\text { Pengetahuan } \\
\text { Responden }\end{array}$} & \multicolumn{4}{|c|}{ Kepatuhan Responden } & \multirow{3}{*}{$\mathbf{n}$} & \multirow{3}{*}{$\%$} & \multirow{3}{*}{$\mathbf{p}$} \\
\hline & \multicolumn{2}{|c|}{ Patuh } & \multicolumn{2}{|c|}{ Tidak Patuh } & & & \\
\hline & f & $\%$ & $\mathbf{f}$ & $\%$ & & & \\
\hline smean & 53 & 88,3 & 5 & 8,3 & 58 & 96,7 & \\
\hline$<$ mean & 2 & 3,6 & 0 & 0 & 2 & 3,3 & $0,002^{*}$ \\
\hline Total & 55 & 91,9 & 5 & 8,3 & 60 & 100 & \\
\hline
\end{tabular}


Jumlah responden dengan pengetahuan tentang anemia lebih besar dari mean dan patuh mengonsumsi tablet besi sebanyak 88,3\%, sedangkan responden dengan pengetahuan tentang anemia lebih besar dari mean namun tidak patuh mengonsumsi tablet besi sebanyak $8,3 \%$. Hasil analisis bivariat menggunakan uji korelasi Spearman's rho menunjukkan nilai $p=$ $0,002(p<0,05)$.

\section{PEMBAHASAN}

Penelitian ini menggunakan responden dalam rentang usia reproduksi yang direkomendasikan WHO, yaitu usia 20-35. Usia memiliki pengaruh yang besar terhadap tingkat pengetahuan seseorang karena berkaitan dengan daya tangkap serta pola pikir seseorang. Semakin bertambahnya usia, semakin bertambah pula pengetahuan yang diperoleh seseorang. Namun, pada usia lanjut, kemampuan penerimaan atau mengingat suatu pengetahuan akan berkurang..$^{11}$ Menurut penelitian Kamidah ${ }^{21}$ tidak ada hubungan antara usia dengan kepatuhan mengonsumsi tablet besi (Fe).

Semakin tinggi tingkat pendidikan, maka semakin mudah menerima informasi, sehingga semakin banyak pengetahuan yang dimiliki, sedangkan tingkat pendidikan yang kurang akan menghambat perkembangan penerimaan nilai-nilai baru yang diperkenalkan. ${ }^{22}$ Seseorang yang memiliki pendidikan tinggi akan lebih terbuka dengan masuknya informasi-informasi baru dan lebih mudah menerima gagasan baru, sehingga akan menambah tingkat pengetahuan dan memengaruhi perilaku yang positif. ${ }^{23}$ Tinggi rendahnya tingkat pendidikan berhubungan dengan tingkat pengetahuan tentang anemia serta kesadaran minum tablet besi pada ibu hamil. Tingkat pendidikan ibu hamil yang rendah berpengaruh terhadap penerimaan informasi sehingga pengetahuan tentang zat besi menjadi terbatas dan berdampak pada konsumsi tablet besi yang rendah. ${ }^{24}$

Ibu hamil yang tidak bekerja atau ibu rumah tangga mempunyai waktu luang lebih banyak untuk dapat mengikuti berbagai penyuluhan dan mencari informasi-informasi tentang anemia. Pengetahuan yang dimiliki ibu hamil yang tidak bekerja ini memiliki pengaruh pada kejadian anemia ibu hamil yang lebih rendah dibandingkan pada ibu hamil yang bekerja. ${ }^{25}$ Namun, dalam perilaku mengonsumsi tablet besi, pekerjaan bukan menjadi satu-satunya faktor utama yang memengaruhi kejadian anemia pada ibu hamil. ${ }^{26}$

Ibu hamil dengan paritas lebih dari satu, memiliki pengalaman yang lebih banyak dibandingkan ibu hamil dengan paritas satu. ${ }^{27}$ Pengetahuan individu salah satunya dibentuk oleh pengalaman. ${ }^{28}$ Pengalaman dapat menambah pengetahuan seseorang melalui cara nonformal. ${ }^{22}$ Pada penelitian ini, sebagian besar responden mempunyai paritas $>1$, sehingga sebagian besar sudah mempunyai pengalaman kehamilan dan persalinan. Penelitian Kamidah $^{21}$ menunjukkan tidak ada hubungan antara paritas dengan kepatuhan konsumsi tablet besi. Hal ini dapat disebabkan oleh adanya pengalaman dari ibu hamil yang 
mengonsumsi tablet besi pada kehamilan sebelumnya yakni pada efek samping yang ditimbulkan seperti mual dan sembelit. ${ }^{29}$

Tingkat paparan informasi responden didominasi oleh kategori satu sumber informasi dengan latar belakang mendapatkan informasi dari petugas kesehatan. Semakin banyak informasi yang dimiliki seseorang, maka akan semakin banyak pula pengetahuannya. ${ }^{11}$ Pengetahuan biasanya diperoleh dari berbagai sumber informasi, seperti tenaga kesehatan, media massa, media elektronik, buku petunjuk kesehatan, poster, saudara, teman, dan sebagainya. ${ }^{30}$ Sebagian besar ibu hamil dalam penelitian ini belum patuh dalam mengonsumsi tablet besi. Berdasarkan pendapat Notoatmodjo, ${ }^{11}$ paparan informasi dapat menimbulkan kesadaran untuk berperilaku sehat dan perilaku yang didasari oleh kesadaran akan berlangsung lama dan langgeng. Namun, proses sampai terbentuknya perilaku memerlukan waktu yang lama.

Hasil penelitian menunjukkan bahwa dukungan keluarga memberikan kontribusi besar pada kepatuhan ibu hamil dalam mengonsumsi tablet besi. Hal tersebut sesuai dengan penelitian yang dilakukan oleh Kamidah ${ }^{21}$ bahwa ibu hamil yang mendapat dukungan keluarga cenderung lebih patuh untuk mengonsumsi tablet besi dibandingkan dengan ibu hamil yang tidak mendapat dukungan keluarga, dimana ibu hamil yang tidak mendapat dukungan keluarga memiliki kecenderungan tidak patuh dalam mengonsumsi tablet besi.

Hasil penelitian menunjukkan bahwa pemberian media audiovisual ini dapat berpengaruh pada pengetahuan ibu hamil. Rerata nilai pre-test yaitu 76,92 , menunjukkan ibu hamil yang memiliki nilai >mean sebesar 33 orang (55\%). Hal ini dapat disebabkan oleh sebagian besar tingkat pendidikan ibu hamil berada pada kategori > 9 tahun atau pendidikan terakhir SMA dan Perguruan Tinggi (PT). Hasil penelitian ini sesuai dengan penelitian yang dilakukan oleh Sundari, ${ }^{31}$ semakin tinggi tingkat pendidikan seseorang, maka hasil penilaian tingkat pengetahuan semakin tinggi pula.

Setelah dilakukan pre-test dan intervensi menggunakan media audiovisual, kemudian dilakukan post-test 1. Dari hasil pre-test dan post-test 1 terdapat peningkatan pengetahuan secara bermakna pada responden. Teknologi dan media pembelajaran dapat digunakan sebagai salah satu upaya dalam meningkatkan kualitas pembelajaran. ${ }^{13}$ Menurut Notoatmodjo, ${ }^{11}$ media promosi kesehatan dapat memberikan pengaruh dalam meningkatkan pengetahuan, yang akhirnya diharapkan dapat merubah perilaku kesehatan ke arah yang lebih baik.

Penggunaan audiovisual dalam pendidikan kesehatan memiliki kelebihan yaitu dapat menampilkan gambar bergerak, menampilkan suatu proses, mempelajari keterampilan tertentu, dan dapat menggugah emosi pengguna melalui dramatisasi dalam video, oleh karena itu penggunaan media audiovisual dapat membentuk sikap baik sikap individu maupun sikap sosial. ${ }^{32}$ Hasil post-test 1 menunjukkan nilai mean 89,00 . Hal ini sesuai dengan penelitian 
Warsita ${ }^{33}$ bahwa kemampuan seseorang dalam menyimpan pesan dengan media audiovisual $<3$ hari sebesar $85 \%$.

Nilai mean post-test 2 lebih tinggi dibandingkan dengan nilai mean post-test 1 yaitu sebesar 92,58. Peningkatan nilai mean ini dapat dipengaruhi oleh beberapa hal, antara lain edukasi tambahan yang diterima oleh responden setelah intervensi dan tindakan mengulang pemutaran video secara rutin yang dilakukan responden. Hanya 3 responden yang menyatakan tidak mengulang pemutaran video setelah dilakukan post-test 1 dan sebanyak 57 responden mengulang pemutaran video 1-7 kali dalam 10 hari. Hal ini sesuai dengan penelitian Syah ${ }^{34}$ bahwa proses belajar yang berulang dalam waktu singkat akan lebih efektif dibandingkan proses belajar yang hanya sekali dalam waktu yang lebih lama.

Penelitian ini sejalan dengan penelitian yang dilakukan oleh Adawiyani ${ }^{35}$ dengan judul "Pengaruh Pemberian Booklet Anemia terhadap Pengetahuan, Kepatuhan Minum Tablet Tambah Darah, dan Kadar Hemoglobin Ibu Hamil", yang menunjukkan bahwa pemberian booklet anemia berpengaruh terhadap pengetahuan ibu hamil, kepatuhan ibu hamil mengonsumsi tablet tambah darah, dan kenaikan kadar $\mathrm{Hb}$.

Hasil penelitian ini menunjukkan adanya pengaruh yang bermakna antara kepatuhan ibu hamil sebelum dan setelah diberikan media audiovisual serta aplikasi Pemitasi. Hasil pengolahan data awal kepatuhan menunjukkan bahwa sebagian besar ibu hamil tidak patuh dalam konsumsi tablet besi. Hal tersebut dipengaruhi oleh ibu hamil yang sering lupa meminum tablet besi karena ketiduran, efek samping tablet besi yang menimbulkan sembelit, dan rasa mual yang dirasakan setelah konsumsi tablet besi. Hal ini sesuai dengan teori Maulana ${ }^{36}$ bahwa video merupakan rekaman suara dan gambar secara elektronis ke dalam pita magnetik yang bertujuan untuk mengubah perilaku seseorang agar bertindak akan sesuatu hal.

Selain media audiovisual, penelitian ini juga menggunakan aplikasi Pemitasi yang digunakan sebagai alarm pengingat minum tablet besi. Fang et al. ${ }^{37}$ mengemukakan bahwa peningkatan kepatuhan terhadap pengobatan melalui sistem pengingat adalah salah satu jenis intervensi yang bermanfaat bagi pasien yang lupa minum obat tanpa sengaja. Aplikasi ponsel juga menjadi semakin populer sebagai cara yang efektif dan nyaman untuk mengingatkan. Hal ini sesuai dengan penelitian Fenerty et al. ${ }^{38}$ bahwa intervensi berbasis pengingat dapat memperbaiki kepatuhan terhadap pengobatan. Hal ini pun sejalan dengan penelitian Boeni et al. ${ }^{39}$ melalui metode systematic review 30 artikel jurnal yang menunjukkan bahwa ada efek positif dari alat pengingat minum obat terhadap kepatuhan minum obat. Penelitian serupa telah dilakukan oleh Alvionita ${ }^{40}$ yang menggunakan poster dan SMS reminder sebagai media penyampaian materi dan pengingat untuk minum tablet besi. Hasil penelitian tersebut menunjukkan, ibu hamil yang mendapatkan poster dan SMS reminder lebih patuh dibandingkan kelompok kontrol. 
Hasil penelitian ini menunjukkan bahwa ada hubungan antara pengetahuan tentang anemia dengan kepatuhan minum tablet besi pada ibu hamil, dimana peningkatan pengetahuan ibu hamil diikuti dengan peningkatan kepatuhanya mengkonsumsi tablet besi. Penelitian ini sejalan dengan penelitian oleh Kamidah ${ }^{20}$ yang menyatakan bahwa semakin tinggi tingkat pengetahuan ibu hamil tentang anemia, maka kepatuhan dalam mengonsumsi tablet besi semakin tinggi pula.

Notoatmodjo ${ }^{11}$ menyebutkan bahwa salah satu faktor yang memengaruhi perilaku adalah pengetahuan. Dengan didasari pengetahuan, perubahan perilaku seseorang akan lebih bertahan lama dari pada perilaku yang tidak didasari oleh pengetahuan. ${ }^{41}$ Pengetahuan seseorang tentang anemia akan memengaruhi perilaku dirinya dalam mengonsumsi tablet besi. Kurangnya pengetahuan ibu hamil tentang anemia dan tablet besi, membuat ibu hamil merasa tidak butuh akan konsumsi tablet besi karena tidak tahu manfaatnya, sehingga menjadikan ibu hamil tidak mau mengonsumsi tablet besi untuk mencegah anemia. Apabila pengetahuan tentang anemia dalam kategori baik, maka ibu hamil akan berusaha untuk mencegah terjadinya anemia pada masa kehamilannya, karena sudah mengetahui efek anemia akan mengganggu kesehatan dirinya maupun bayi yang dikandung. ${ }^{41}$

Selain pengetahuan, terdapat faktor lain yang memengaruhi kepatuhan ibu dalam mengkonsumsi tablet besi. Dalam penelitian ini, ada ibu hamil yang memiliki pengetahuan $<$ mean tetapi patuh dalam mengonsumsi tablet besi dikarenakan adanya peran suami dan aplikasi Pemitasi dalam mengingatkan jadwal mengonsumsi tablet besi pada ibu hamil. Hasil penelitian ini sejalan dengan penelitian yang dilakukan Kamidah ${ }^{21}$ bahwa ibu hamil yang mendapat dukungan keluarga, cenderung lebih patuh untuk mengonsumsi tablet besi.

Kelemahan pada penelitian yaitu cara pengambilan data post-test (setelah 10 hari) tidak seragam, dari 60 responden ada 37 ibu hamil dilakukan post-test melalui daring via WhatsApp, sebagai antisipasi, peneliti memberikan waktu menjawab post-test selama 30 menit. Peneliti tidak melakukan kontrol terkait bias interaksi antar-responden. Rentang pengambilan data selama 10 hari, memungkinkan responden saling bertemu, saling bertukar dan mencari informasi terkait anemia pada kehamilan. Peneliti juga tidak melakukan kontrol terkait anggota keluarga ibu hamil yang mengingatkan ibu hamil untuk meminum tablet besi. Dari ketiga pemaparan kelemahan penelitian di atas, hal tersebut dapat menimbulkan bias pada hasil penelitian.

\section{KESIMPULAN DAN SARAN}

Pada penelitian ini, pemberian media audiovisual dan aplikasi Pemitasi berpengaruh meningkatkan pengetahuan tentang anemia dan kepatuhan minum tablet besi pada ibu hamil dan terdapat hubungan antara pengetahuan tentang anemia dengan kepatuhan minum tablet besi pada ibu hamil. 
Peneliti selanjutnya diharapkan dapat mengembangkan media audiovisual dan aplikasi Pemitasi yang digunakan, karena pada penelitian ini media audiovisual dan aplikasi masih dalam bentuk sederhana. Selain itu, penelitian ini menggunakan responden dengan latar belakang yang hampir sama. Maka, perlu dilakukan pengujian ulang hubungan antara pengetahuan dengan kepatuhan pada kelompok kontrol, dan perlu membandingkan tempat yang berbeda, antara puskesmas dengan kemampuan PONED dan puskesmas tanpa PONED.

\section{UCAPAN TERIMA KASIH}

Terima kasih peneliti sampaikan kepada responden yang telah berpartisipasi pada penelitian ini, ibu Wiwin Lismidiati yang telah berkenan memberikan saran dan arahannya, asisten penelitian yang telah membantu selama proses pengambilan data, dan seluruh pihak yang terlibat, sehingga proses penelitian ini dapat berjalan lancar.

\section{DAFTAR PUSTAKA}

1. World Health Organization (WHO). The Global Prevalence of Anemia in 2011. Switzerland: WHO; 2011.

2. Allen LH. Anemia and Iron Deficiency: Effects on Pregnancy Outcome 1-3. 2000; 71: 1280-4. Available from: ajcn.nutrition.org.

3. Manuaba. Pengantar Kuliah Obstetri. Jakarta: EGC; 2007. 559 p.

4. Leveno KJ, Cunningham FG, Alexander J, Bloom SL, Casey BM, Dashe JS, Williams. Manual of Obstetrics Pregnancy Complications. 22nd ed. U.S Amerika: Mc Graw Hill Medical; 2008.

5. Dinas Kesehatan. Profil Kesehatan Provinsi D.I.Yogyakarta tahun 2011. Yogyakarta: Dinkes DIY; 2012.

6. Azra PA, Rosha BC. Faktor-Faktor yang Berhubungan dengan Status Anemia Ibu Hamil di Wilayah Kerja Puskesmas Air Dingin Kecamatan Kota Tengah, Kota Padang. Jurnal Kesehatan Reproduksi. 2015; (April): 89-96.

7. Dinkes. Profil Kesehatan Kabupaten Bantul Tahun 2015. Bantul: Dinkes Bantul; 2016. p. 25.

8. Kemenkes. Riset Kesehatan Dasar 2013. Jakarta: Riskesdas; 2013.

9. Utomo APW. Hubungan Asupan Zat Gizi dan Tingkat Kepatuhan Mengonsumsi Tablet Besi dengan Kejadian Anemia pada Ibu Hamil di Wilayah Kerja Puskesmas I Kembaran Kabupaten Banyumas [Thesis]. Yogyakarta: Fakultas Kedokteran, Kesehatan Masyarakat, dan Keperawatan, Universitas Gadjah Mada; 2014.

10. Nursalam. Metodologi Penelitian IImu Keperawatan: Pendekatan Praktis. 3rd ed. Jakarta: Salemba Medika; 2013.

11. Notoatmodjo. Ilmu Perilaku Kesehatan. Jakarta: Rineka Cipta; 2010.

12. Nurhidayati RD. Analisis Faktor Penyebab Terjadinya Anemia pada Ibu hamil di Wilayah Kerja Puskesmas Tawangsari Kabupaten Sukoharjo [Skripsi]. Surakarta: Fakultas IImu Kesehatan, Universitas Muhammadiyah Surakarta; 2013.

13. Smaldino S, Russell J. Instructional Technology and Media for Learning. New Jersey: Prentice Hall; 2005.

14. Nursalam, Efendi F. Pendidikan dalam Keperawatan. Jakarta: Salemba Medika; 2008.

15. Siregar S. Statistik Parametrik untuk Penelitian Kuantitatif. Jakarta: Bumi Aksara; 2013. 61 p.

16. Sulistyowati D. Tingkat Pengetahuan Ibu Hamil tentang Anemia di Puskesmas Gambisari Surakarta. 2012; Available from: http://digilib.stikeskusumahusada.ac.id/filesdisk/2/01-gld-frdinasuli-66-1-ktifrd-i.pdf

17. Widyawati. Kiat Sehat bagi Ibu Hamil dengan Anemia. 1st ed. Yogyakarta: PSIK FK UGM; 2012. $26-27$ p.

18. Riwidikdo. Metodologi Penelitian Kesehatan. Jakarta: Bina Pustaka; 2007.

19. Suryono. Metodologi Penelitian Kesehatan. Yogyakarta: Mitra Cendikia Press; 2008.

20. Depkes. Pedoman Pelayanan Antenatal Terintegrasi. Jakarta: Bina Kesehatan Masyarakat; 2010.

21. Kamidah. Faktor-Faktor yang Memengaruhi Kepatuhan Ibu Hamil Mengonsumsi Tablet Fe di Puskesmas Simo Boyolali. Gaster. 2015;12(1):36-45.

22. Wawan A, Dewi M. Teori dan Pengukuran Pengetahuan, Sikap dan Perilaku Manusia. Yogyakarta: Nurha Medika; 2010.

23. Walyani SE. Asuhan Kebidanan Yogyakarta. Jakarta: EGC; 2015.

24. Elisabeth L. Asuhan Kebidanan Kehamilan. Jakarta: In Media; 2013.

25. Purbadewi L, Setiawan YN. Hubungan Tingkat Pengetahuan tentang Anemia dengan Kejadian Anemia pada Ibu Hamil. Jurnal Gizi Universitas Muhammadiyah Semarang. 2013;2(1):31-39.

26. Mubarak WI. Promosi Kesehatan: Sebuah Pengantar Proses Belajar Mengajar dalam Pendidikan. Yogyakarta: Graha IImu; 2007.

27. Amrina R. Hubungan Tingkat Pengetahuan Ibu Hamil tentang Gizi Selama Kehamilan [Skripsi]. Surakarta: 
STIKes Kusuma Husada Surakarta; 2013.

28. Bimo W. Pengantar Psikologi Umum. Jakarta: Gramedia Pustaka Utama; 2004.

29. Kautshar N, Suriah, Jafar N. Kepatuhan Ibu Hamil dalam Mengonsumsi Tablet Zat Besi (Fe) di Puskesmas Bara-Braya [Thesis]. Makassar: Fakultas Kesehatan Masyarakat, Universitas Hasanuddin; 2013.

30. Manuaba IBG. IImu Kebidanan, Penyakit Kandungan \& Keluarga Berencana untuk Pendidikan Bidan. Jakarta: Buku Kedokteran EGC; 1998.

31. Sundari A, Aulawi K, Harjanto D. Gambaran Tingkat Pengetahuan tentang Ulkus Diabetik dan Perawatan Kaki pada Pasien Diabetes Melitus Tipe 2 [Skripsi]. Yogyakarta: Fakultas Kedokteran, Kesehatan Masyarakat, dan Keperawatan, Universitas Gadjah Mada; 2009.

32. Tim Dosen PAl. Bunga Rampai Penelitian dalam Pendidikan Agama Islam. Yogyakarta: Deepublish; 2016.

33. Warsita B. Teknologi Pembelajaran, Landasan, dan Aplikasinya. Jakarta: Rineka Cipta; 2008.

34. Syah M. Psikologi Pendidikan. Jakarta: Raja Grafindo Persada; 2015.

35. Adawiyani R. Pengaruh Pemberian Booklet terhadap Pengetahuan, Kepatuhan Minum Tablet Tambah Darah, dan Kadar Hemoglobin pada Ibu Hamil. Calyptra: Jurnal IImiah Mahasiswa Universitas Surabaya. 2014; 2(2).

36. Maulana H. Promosi Kesehatan. Jakarta: Buku Kedokteran EGC; 2009.

37. Fang KY, Maeder AJ, Bjering H. Current Trends in Electronic Medication Reminders for Self-Care. Australia: Flinders University 2016.

38. Fenerty S, West C, Davis S, Kaplan S, Feldman S. The Effect of Reminder Systems on Patients Adherence to Treatment. Patient Prefer Adherence. 2012; 6: 127-35.

39. Boeni F, Spinatsch E, Suter K, Hersberger K, Arnet I. Effect of Drug Reminder Packaging on Medication Adherence. BioMed Central. 2014.

40. Alvionita I. Pengaruh Pemberian Poster dan SMS Reminder terhadap Kepatuhan Minum Tablet Besi dan Kenaikan Kadar Hb lbu Hamil di Wilayah Kerja Puseksmas Sukoharjo [Skripsi]. Surakarta: Fakultas IImu Kesehatan, Universitas Muhammadiyah Surakata; 2017.

41. Muzayana A, Santosa S, Arum DNS. Hubungan Tingkat Pengetahuan dengan Kejadian Anemia pada Ibu Hamil di Wilayah Puskesmas Godean I. Jurnal Kesehatan Ibu dan Anak. 2016;9(1). 